\title{
SPECIFICS OF UTILITIES DESIGN USING INFORMATION MODELING
}

\author{
Oksana Medvedeva1, Tatyana Sautkina ${ }^{2}$ \\ ${ }_{1,2}$ Yuri Gagarin State Technical University of Saratov \\ 77 Politechnicheskaya street, Saratov, Russia \\ ${ }^{1}$ Corresponding author: medvedeva-on@mail.ru
}

\begin{abstract}
Introduction: Building information modeling is currently intensively used in the construction industry, helping to automate design processes starting from the development of drawings and ending with the BOM preparation. BIM technologies are useful in the design and development of documentation for various design sections (heating, ventilation, outdoor gas and water supply systems) as they make it possible to avoid project mistakes. Purpose of the study: The paper is aimed to review the specifics of developing information models for utilities and analyze issues arising in the course of design. Methods: In the present paper, methods of theoretical research are used. Results: The authors studied mechanisms of information modeling for utilities, identified issues arising during design documentation development, and suggested methods of solving staffing problems.
\end{abstract}

Keywords: information modeling, BIM platform, utilities, technologies, innovations

\section{Introduction}

BIM (Building Information Modeling) is a process of information creation and management at all stages of the facility's life cycle. Steps taken by various countries give a boost to the rapid development of BIM technologies. In some countries, implementation of BIM standards is state-regulated, while in others it is advisory rather than mandatory. However, in all cases, those are detailed documents intended to improve the economic efficiency of investment construction projects. In the last few years, some new approved standards were introduced into the Russian regulatory framework: State Standard GOST R 57310-2016 "Building information models. Information delivery manual. Methodology and format" (ISO 294811:2010); State Standard GOST R 57563-2017 “Buildings and structures information modeling. General principles for the development of buildings and constructucions information modelling standards" (ISO/TS 12911:2012); State Standard GOST R 57311-2016 "Building information modelling. Requirements for operation and maintenance documentation for built asset"; State Standard GOST R 57309-2016 "Guidelines for knowledge libraries and object libraries" (ISO 16354:2013); State Standard GOST R ISO 12006-2-2017 "Building. Model of construction works data organization. Part 2. Basis of information classification" (ISO 12006-2:2015); State Standard GOST R 12006-3-2017 "Building. Model of construction works data organization. Part 3. Basis for objectoriented information interchange" (ISO 12006-3:2007); State Standard GOST R UCO 22263-2017 "Model of construction works data organization. Framework for management of design information" (ISO 22263:2008); Regulations SP 301.1325800.2017 "Building information modeling. Rules for the organization of work by the production and technical departments"; Regulations
SP 333.1325800.2017 "Building information modeling. Modeling guidelines for various project life cycle stages"; Regulations SP 328.1325800.2017 "Building information modeling. Components. Guidelines and requirements"; Regulations SP 331.1325800.2017 "Building information modeling. Modeling guidelines and requirements of exchange data between building information models and application package models", etc. A review of national and international scientific literature revealed a large number of publications dedicated to BIM implementation efficiency (Blanco and Chen, 2014; Kannan and Santhi, 2014; Kristianto et al., 2014; Reizgevičius et al., 2013; Ziganshin and Ziganshin, 2018, and others). Russian literature has enough sources describing work with BIM tools as well as challenges associated with the implementation of BIM in Russia (Boykov et al., 2015; Chervova and Lepeshkina, 2018; Lyalin et al., 2017; MGSU report, 2016; Pykhtin et al., 2017; Sharmanov et al., 2015; Ziganshin and Ziganshin, 2018, and others). One of the main advantages of information modeling over computer-aided design (CAD) is a possibility to track changes in adjacent design sections, exchange data, and introduce changes in real time (Boykov et al., 2015; Chervova and Lepeshkina, 2018; Lyalin et al., 2017; Pykhtin et al., 2017; and others).

Nowadays, most employers in the construction industry expect graduates to have basic skills in using software tools and working with BIM elements.

\section{Subject, tasks and methods}

According to some experts (Chervova and Lepeshkina, 2018; MGSU report, 2016; Astafieva et al., 2017), among the main reasons hindering wide BIM implementation in Russia, the following shall be mentioned: significant initial expenses for necessary equipment and software 
(most construction companies are not ready to spend 200,000-1,000,000 rubles per employee); shortage of qualified specialists having relevant competencies and experience in the BIM field; a need to restructure the company when stepping away from traditional design methods and implementing the teamwork principle in a particular information environment (which is often accompanied by some decrease in labor efficiency due to training to work under new conditions, longer design time, and lack of significant economic effects when starting to use new technologies); a need to adapt foreign software supporting the BIM process to the requirements of the domestic regulatory framework, etc. Despite some difficulties, the following advantages of new technologies are beyond question: an increase in the speed of design documentation development and improvement of its quality; detailed estimation of construction and installation works; a possibility to reduce errors (e.g. detect interferences between structural units and utilities, which is impossible in case of 2D drawings); improvement of project quality in general; a capacity to construct and operate a facility in a virtual space.

A study performed by Autodesk (Autodesk. Building Information Modeling in industrial and civil engineering) presents the following results of using BIM: cost reduction by $10 \%$; a decrease in project delivery time by $7-15 \%$; estimate accuracy improvement by $3 \%$; a decrease in construction estimate development time by $80 \%$; reduction in construction rejects and waste by $30 \%$. Presenting results of its studies, the Ministry of Construction Industry, Housing and Utilities Sector (Minstroy) of the Russian Federation argues that BIM implementation improves a number of performance indicators. It reduces construction and operation costs by $30 \%$; errors in design documentation - by up to $40 \%$; project delivery time - by up to $50 \%$; time spent for model checking - by a factor of 6 ; the percentage of error upon budget planning - by a factor of 4 ; coordination and approval time - up to $90 \%$; construction period - by $10 \%$; design period - by $20-50 \%$.

The following methods of using BIM are the most common:

- 3D visualization. Using this function, it is possible to create a 3D model of a facility (building, structure), perform a visual analysis of a facility, print a mockup on a 3D printer, test a structure, and edit such a model.

- Clustered data storage and integrated data management. All data on a designed facility are within the same group of linked drawings (within the same program). Therefore, a change in one of the parameters automatically leads to changes in other elements, thus reducing the error probability.

Currently, 3D modeling is a standard tool in the design of boiler houses, utilities, linear facilities, including gas pipelines (Figure 1). A geo-referenced 3D model of an actual plant, based on its 2D master plan, involving all its utilities, improves visualization of data on the plant and its performance.

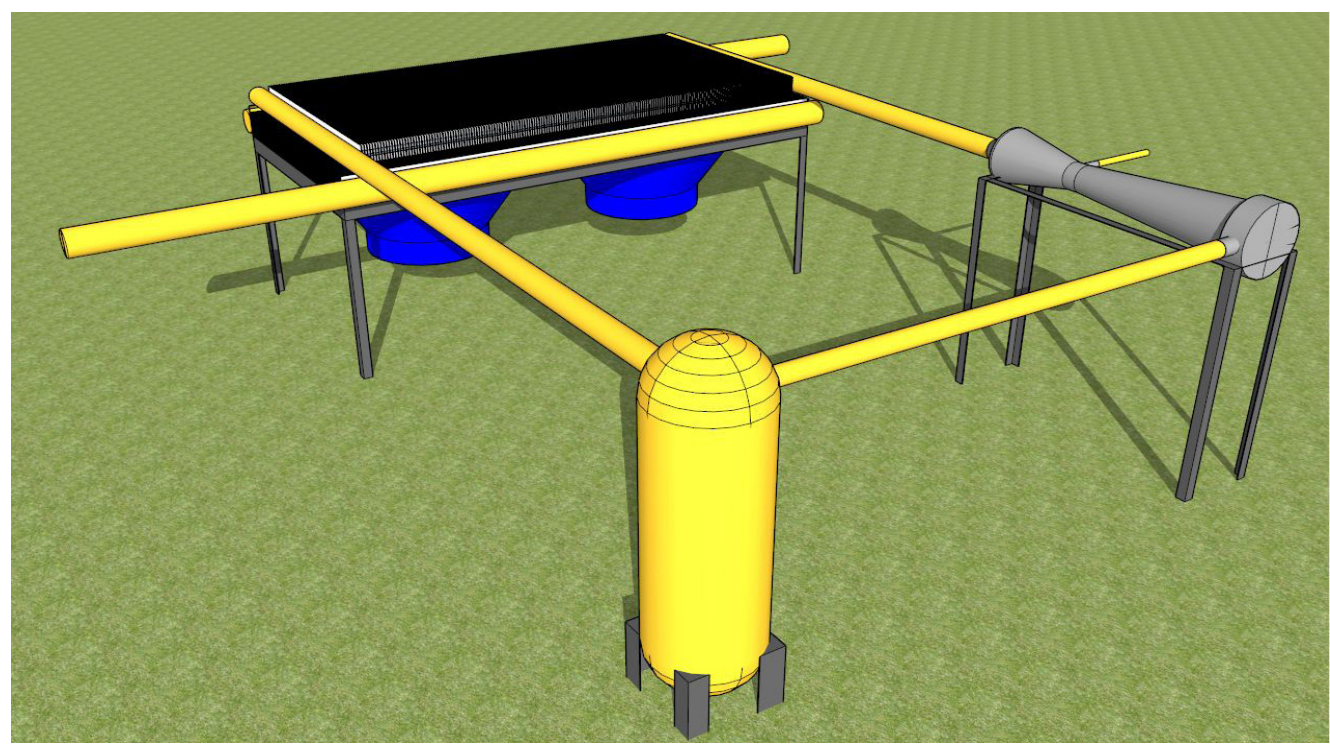

Figure 1. 3D model of a heat exchanger

For automated design and work with utilities (heat, gas and water supply; sewerage; storm drainage), several software programs are proposed, e.g. ENGCAD by ZWSOFT with BIM application in the ZWCAD Professional, AutoCAD, BricsCAD environment (see https://www.zwsoft.ru/): With regard to each type of utilities, the program solves the following tasks: utility summary plan formation, detailed design of water-conduit wells, development of a table of wells, generation of initial data for a facility specification, determination of borehole location, development of volume tables showing cut and fill volumes. It is also possible to choose from various 
templates of tables under the profile. The utility route location is performed in the ZWCAD, AutoCAD (or any other graphic editor) environment, based on an available underlay drawing (Figure 2).

Using a special function, a designer can mark restricted areas (a table of minimum distances is provided in the program). During utility route location, a user shall only specify wells and bending points; the program automatically detects intersections with existing and designed utilities (Figure 3).

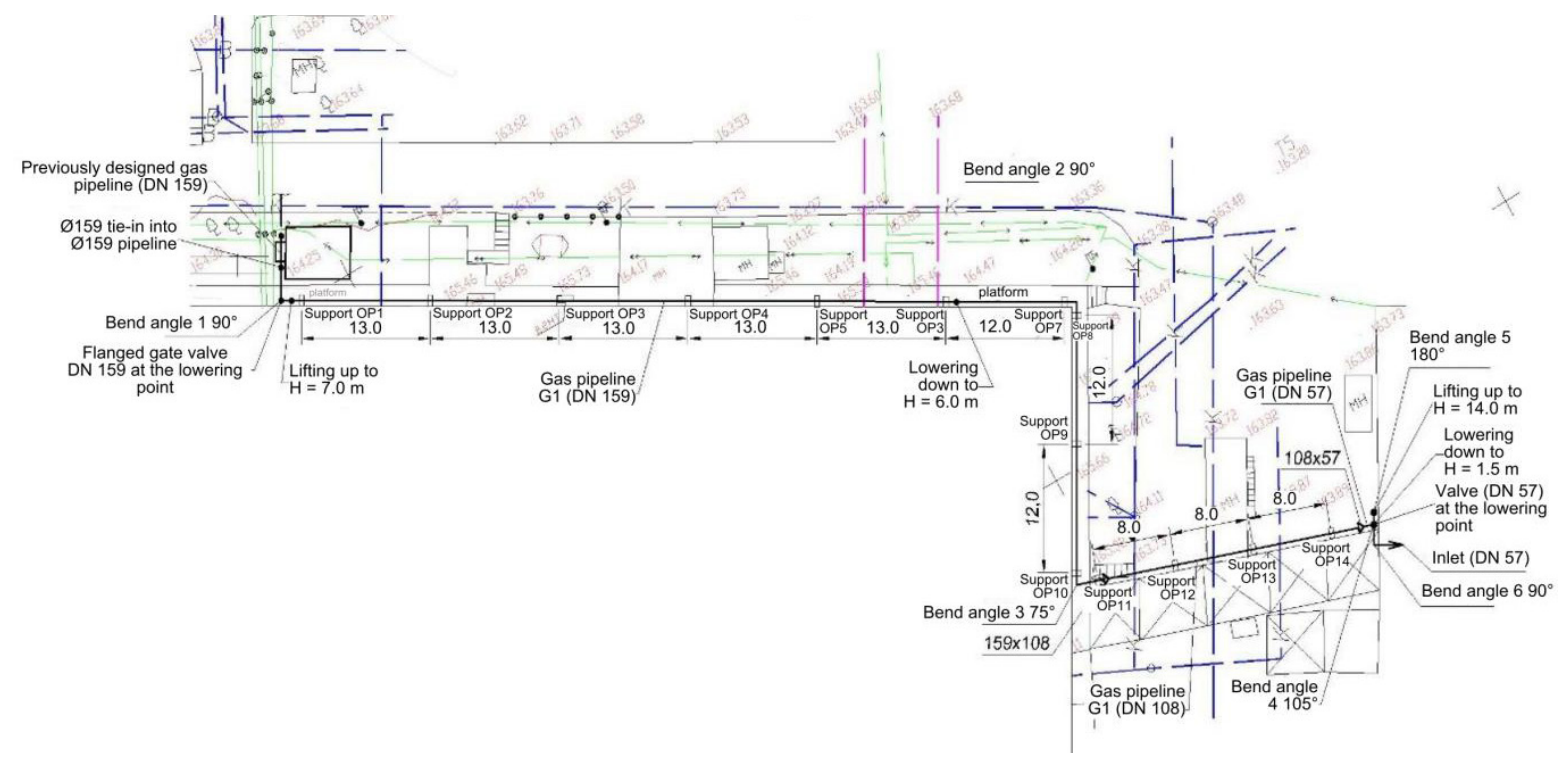

Figure 2. Gas pipeline route being designed

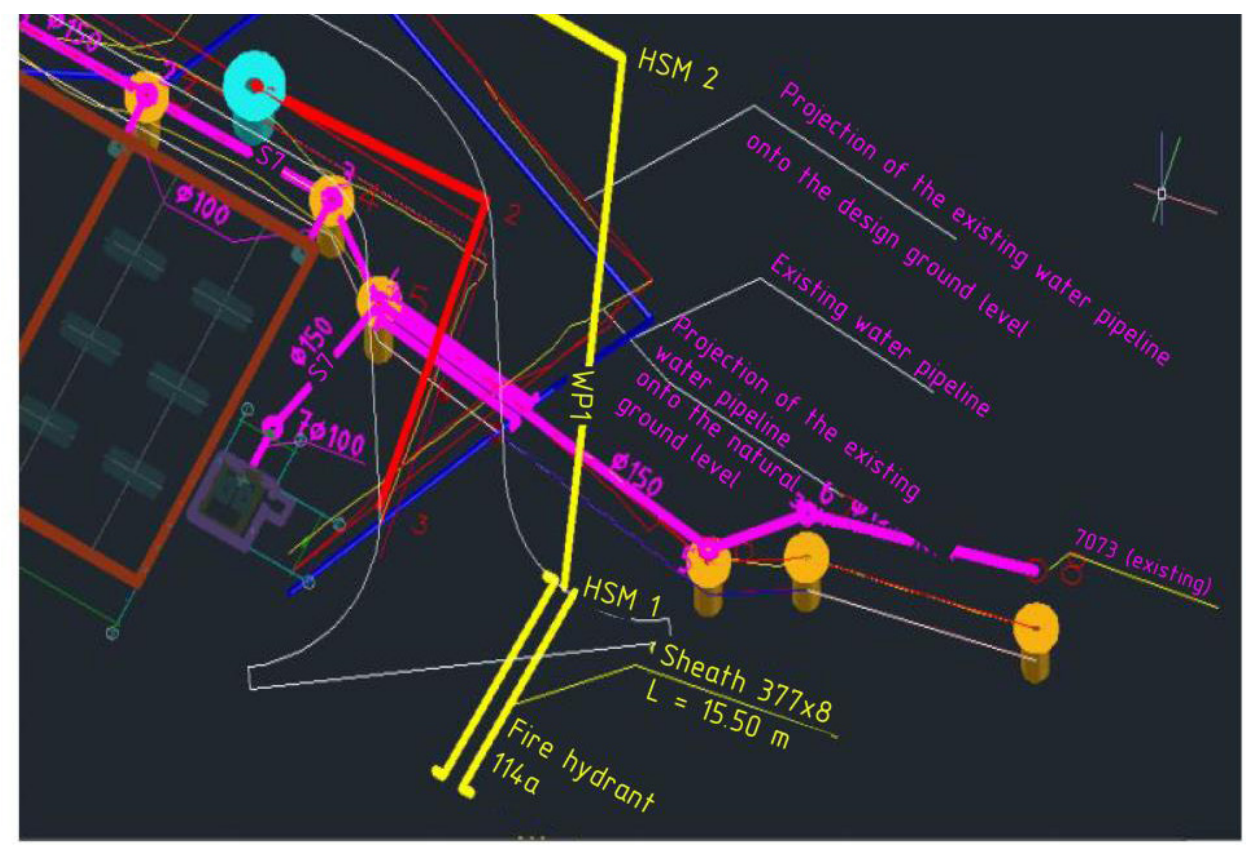

Figure 3. Axonometric diagram of underground utilities being designed (see https://www.zwsoft.ru/eng)

To perform 3D design of intrasite, intradepartmental and interdepartmental pipeline systems, including process pipelines, steam and hot water pipelines, water and gas supply systems, heating systems, and sewerage, it is convenient to use Model Studio CS Pipelines software suite developed by CSoft Development. With its help, it is possible to perform all necessary checks to detect collisions, intersections, and violations of minimum distances. Besides, the collision check system provides a possibility to analyze distances between pipelines and their elements, equipment, structures, cables, and other objects.

\section{Results and discussion}

One of the most essential components of proper switching to BIM technologies is training of skilled 
specialists able to work with information models, which requires mandatory training of students in the use of BIM-oriented programs. In most educational institutions, the training process is still limited to $2 \mathrm{D}$ design. In most cases, to write term papers and graduation theses, students use Autodesk family programs (AutoCAD, ArchiCAD). However, they do not allow for full BIM introduction in the educational process at all design stages. Meanwhile, Autodesk family programs offering integrated solutions to implement BIM technologies (e.g. Autodesk Revit, Autodesk Design Review, Autodesk BIM 360; Autodesk Revit MEP to manage utility infrastructure projects; Autodesk Navisworks to develop "Technology and Organization of Construction and Installation Works" design sections, etc.) can be used in the educational process.

Specialists emphasize that it is necessary to create an educational environment close to the professional one, develop teamwork skills in students, teach them how to master new computer tools and adapt promptly to shifts and changes.

The interest of students in education, development of a professional mindset, gaining of initial practical experience is an important condition of their successful adaptation to future professional activities. To ensure such adaptation to the fullest extent possible, on-the-job training and research activities are required. Training of students majoring in civil engineering shall be based on the wide use of information technologies in the educational process, mastering of CAD systems and 3D models of various technical objects.

Let us provide several examples of implementing practice-oriented assignments within the framework of basic training of students majoring in civil engineering. Students are offered to perform not only obligatory assignments in 2D (e.g. design of a construction site, development of a building plan and section views, preparation of drawings with the design of utilities, structural units) but also creative assignments implying independent work and use of innovative design technologies.

Creative work on an assignment consists of the following stages:

1. Stage 1 - analysis of initial data.

2. Stage $2-3 D$ modeling of an object.

3. Stage 3 - execution of design documentation and preparation to project presentation:

- project visualization;

- generation of an associate drawing with structural elements;

$-3 D$ mockup printing.

4. Stage 4 (final stage) - presentation of the project and its submission for critical review (e.g. at annual competitions of scientific and technical creativity of youth).

Projects can be developed individually or in a team.

For instance, in the course of their research, students at the Department of Heat and Gas Supply, Ventilation, Water Supply, and Applied Fluid and Gas Dynamics of the Yuri Gagarin State Technical University of Saratov designed a laboratory installation to study hydraulic modes of gas supply systems (Izotova and Fominykh, 2017). For a comprehensive study of gas pipeline operation, it is necessary to measure pressure and, based on those measurements, construct pressure maps (a piezometric graph). Using those maps, it is easy to determine areas with the maximum differential pressure and areas with pipe clogging.

The project concept was as follows:

- to develop an appearance model of a gas distribution pipeline;

- to make it possible to model gas consumption by various users in case of changes in demand in separate areas;

- to engage students (including school students) in processes of simulation modeling.

A diagram and a 3D model of the installation, a laboratory bench photo are presented in Figures 4-7.

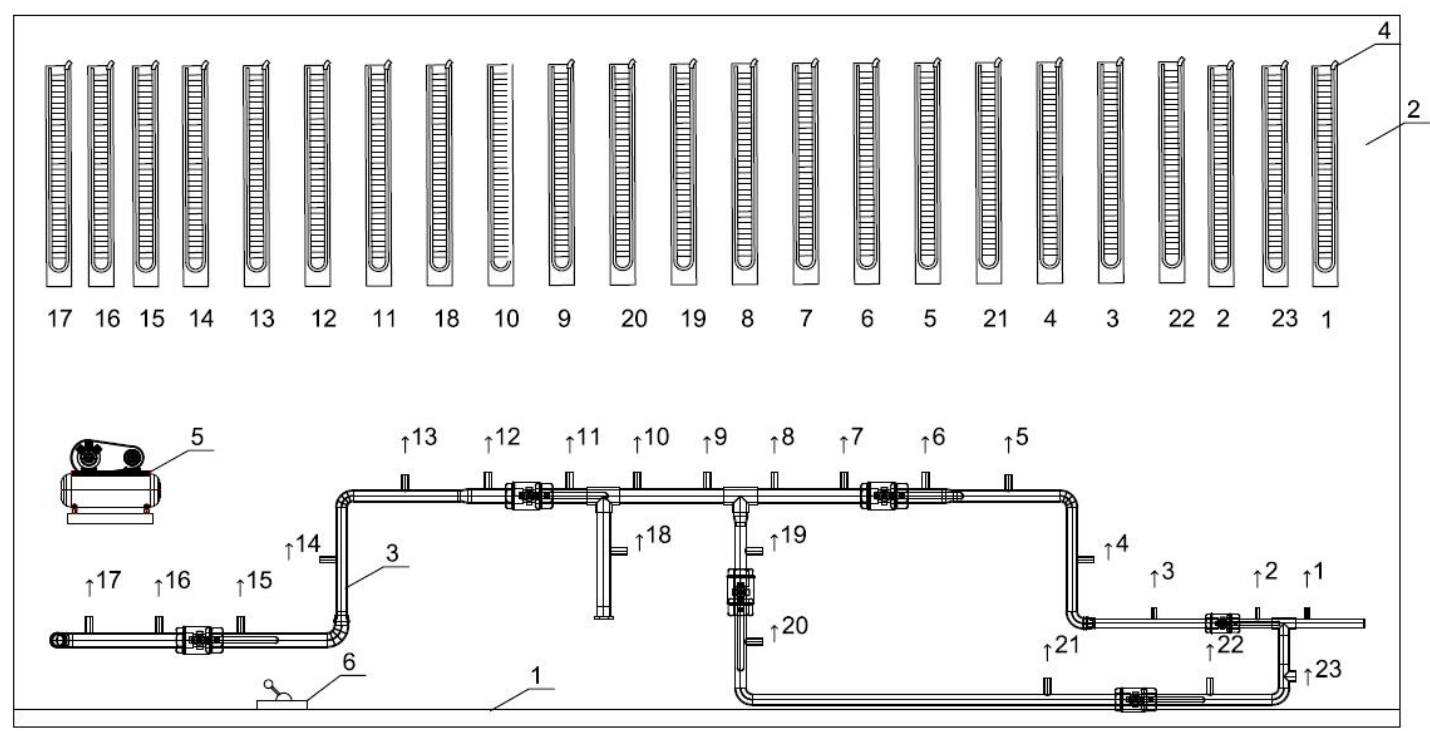

Figure 4. Diagram of the experimental installation 
A low-pressure gas supply system is assembled on bench 1 (Figure 4). Gas supply system 3, which consists of bends, reducers, and valves, is fixed to wall 2 . To measure pressures in characteristic points, liquid pressure gauges connected to pressure taps with flexible tubing are fixed to the bench. To feed air to the gas pipeline, compressor 5 is used, which is connected to a tank through a pressure control valve. Start and shutdown of the installation are performed with switch 6 .

With the help of that installation, it is possible to obtain dependences of gas velocity on pressure and determine the gas flow rate.

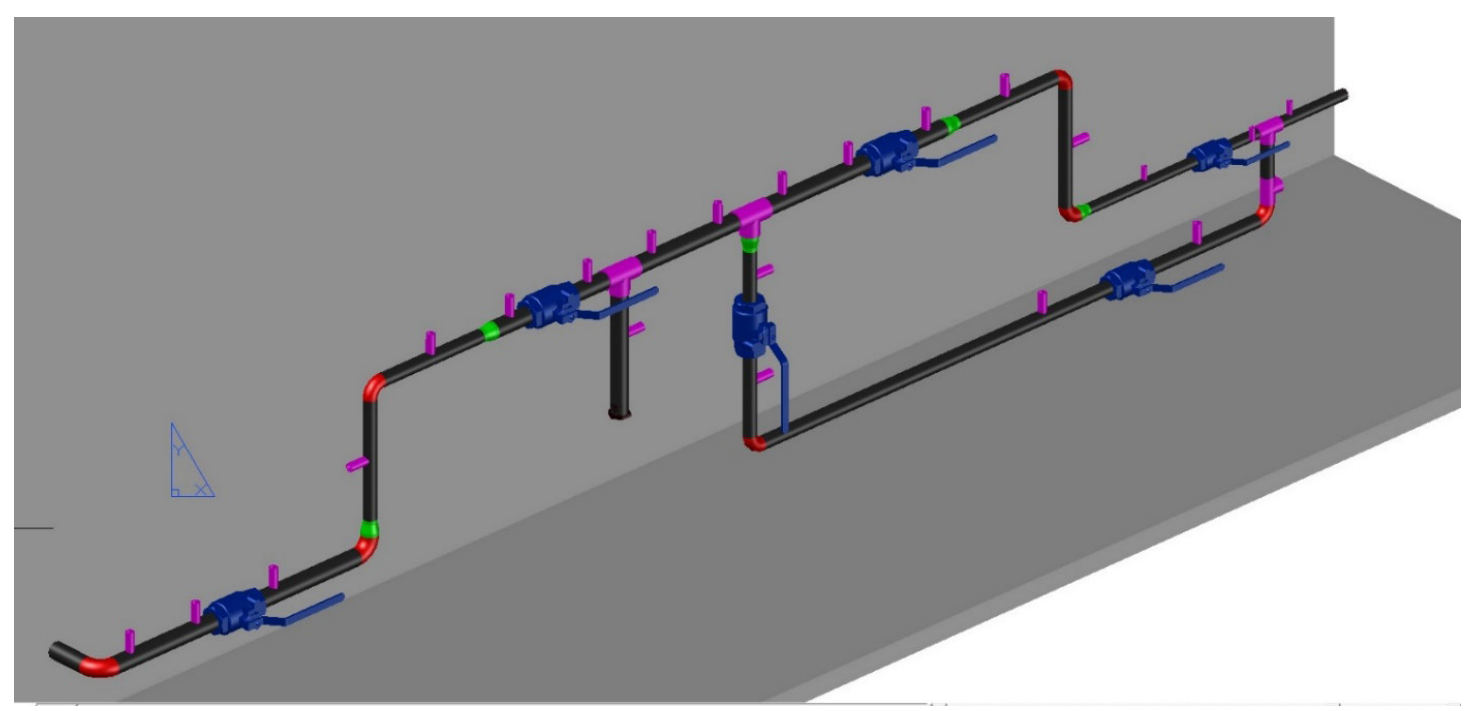

Figure 5. 3D model of a section of the experimental installation

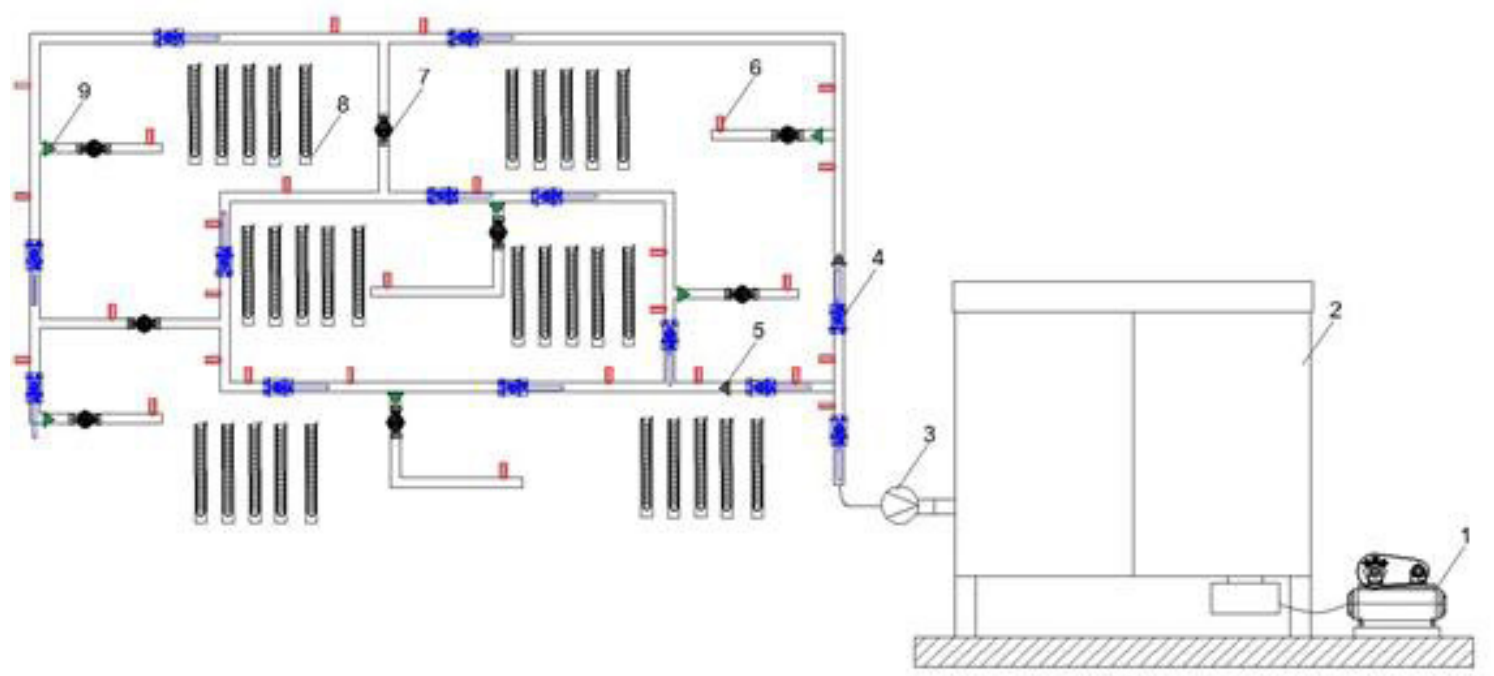

Figure 6. Diagram of the laboratory bench: 1 - compressor unit; 2 - reducing unit; 3 - gas meter; 4 - ball valve; 5 - reducer DN 32/35; 6 - outlet for a pressure gauge; 7 - globe valve; 8 - U-shaped pressure gauge; 9 - reducer DN 25/20

Final results of the project are as follows:

- manufacturing of an experimental prototype simulating a low-pressure gas supply system in a populated area;

- analysis of medium pumping intensity effect on the pipe friction and local drag coefficients;

- clear demonstration of pressure changes upon various system configurations.
In their practical activities, engineers and technicians need to address issues related to the design of gas distribution and gas use equipment, studies of their operation. Experimental data allow for additional analytical studies. Using the installation proposed, it is possible to study the behavior of gas traveling in a pipeline. It is also possible to create such conditions, under which students will be able to apply their knowledge in the field of structural design. 


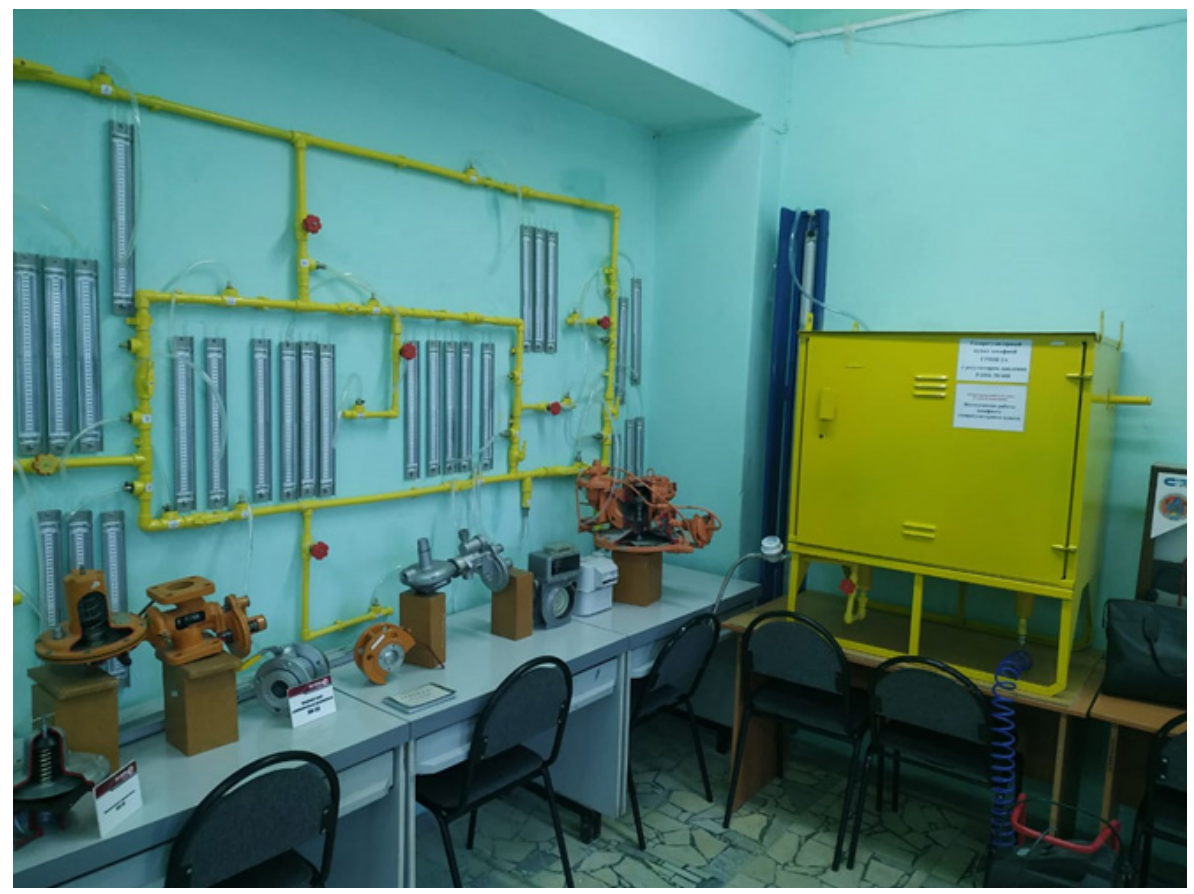

Figure 7. Laboratory bench assembly

\section{Conclusions}

- Information modeling technologies have changed the process of facility design, construction and operation since design is performed in a $3 \mathrm{D}$ space with account for the time factor (4D), i.e. an object-oriented digital model includes the object itself, the process of its construction and further disposal.

- Information modeling improves profitability, reduces time and money expenditures.

- A BIM model contains information on the facility designed, which can be used at all stages of its life cycle, and that is very important.

- When utilities are designed using BIM platforms, it is necessary to perform regular checks to detect intersections and, thus, prevent collisions.

-Using BIM principles, it is possible to visualize, design, detail, and manufacture utilities of complex configuration.

- A BIM model is needed to be shared among all construction participants.

- Due to BIM technologies, it is possible to reduce the number of errors in design documentation, thus optimizing the construction process.

- The use of Green BIM (symbiosis of green construction and information modeling) results in the minimization of expenses for energy resources and utilities.

- BIM technologies allow companies to control the quality of initial design documentation and estimates, organize safe construction works, optimize logistics, and make quality control easier.

- It is necessary to improve knowledge of BIM technologies in both professional designers and future specialists.

- Implementation of BIM training in the educational process requires teachers to improve their skills and take training courses in specialized organizations.

- Purchasing of the necessary software (offering an integrated solution to work with BIM projects at all design stages, and determine construction duration and cost) by universities on special terms will allow such institutions to establish a system of professional training with the use of innovative technologies with account for the life cycle of a construction facility.

- To train sought-after technical experts, it is required to create a realistic educational

environment.

- Students welcome with interest improved educational technologies, which promote professional competencies, demanded by the Federal State Educational Standard, in accordance with real needs in the construction industry.

- It is required to mobilize potential employers around the issue of implementing BIM technologies in the educational process and training specialists based on the modular competency-based approach. 


\section{References}

Astafieva, N.S., Kibireva, J.A., Vasileva, I.L. (2017). Advantages of using and difficulties in implementing of building information modeling. Construction of Unique Buildings and Structures, 8, pp. 41-62.

Autodesk. Building Information Modeling in industrial and civil engineering. Available at: https://damassets.autodesk.net/content/dam/autodesk/www/campaigns/BTT-RU/BIM\%20for\%20buildings_Autodesk.pdf (accessed on: 26.04.2019).

Blanco, F.G.B., Chen, H. (2014). The Implementation of Building Information Modeling in the United Kingdom by the Transport Industry. Procedia-Social and Behavioral Sciences, 138, pp. 510-520.

Boykov, V.N., Mirza, N.S., Petrenko, D.A., Skvortsov, A.V. (2015). IndorCAD 10 as BIM-tool for project analysis and conflicts detection. CAD \& GIS for Roads, 2, pp. 108-113. DOI: 10.17273/CADGIS.2015.2.16.

Chervova, N.A., Lepeshkina, D.O. (2018). Collisions of general utilities designing through the use of BIM-platforms. Construction of Unique Buildings and Structures, 3, pp. 19-29.

Federal Agency for Technical Regulation and Metrology (Rosstandart) (2018). Building information modeling. Modeling guidelines and requirements of exchange data between building information models and application package models. Regulations SP 331.1325800.2017. Moscow: Ministry of Construction Industry, Housing and Utilities Sector (Minstroy) of the Russian Federation, $39 \mathrm{p}$.

Federal Agency for Technical Regulation and Metrology (Rosstandart) (2018). Building information modeling. Modeling guidelines for various project life cycle stages. Regulations SP 333.1325800.2017. Moscow: Ministry of Construction Industry, Housing and Utilities Sector (Minstroy) of the Russian Federation, $40 \mathrm{p}$.

Federal Agency for Technical Regulation and Metrology (Rosstandart) (2018). Building information modeling. Rules for the organization of work by the production and technical departments. Regulations SP 301.1325800.2017. Moscow: Ministry of Construction Industry, Housing and Utilities Sector (Minstroy) of the Russian Federation, $34 \mathrm{p}$.

Federal Agency for Technical Regulation and Metrology (Rosstandart) (2018). Building information modeling. Components. Guidelines and requirements. Regulations SP 328.1325800.2017. Moscow: Ministry of Construction Industry, Housing and Utilities Sector (Minstroy) of the Russian Federation, 21 p.

Izotova, E.A., Fominykh, G.S. (2017). Investigation of the gas network work. Resource- and Energy-Efficient Technologies in the Construction Industry of the Region, 8, pp. 236-239.

Kannan, M.R., Santhi, M.H. (2013). Constructability Assessment of Climbing Formwork Systems Using Building Information Modeling. Procedia Engineering, 64, pp.1129-1138.

Kristianto, M.A., Utama, N.A., Fathoni, A.M. (2014) Analyzing Indoor Environment of Minahasa Traditional House Using CFD. Procedia Environmental Sciences, 20, pp. 172-179.

Lyalin, D.O., Mashtaler, S.N., Dmitrenko, E.A. (2017). Application of the Autodesk Revit software complex in project activities. Proceeding of the Donbas National Academy of Civil Engineering and Architecture, 3, pp. 23-27.

National Association of Designers and Surveyors (2016). Report. Evaluation of BIM application in construction. Results of studying the efficiency of BIM application in investment and construction projects of Russian companies. Moscow: Moscow State University of Civil Engineering (MGSU) National Research University, OOO Concurator, 47 p. Available at: http://nopriz.ru/upload/iblock/2cc/4.7_bim_rf_otchot.pdf (accessed on: 26.04.2019). 


\section{Architecture and Engineering Volume 4 Issue 3}

Pykhtin, K., Simankina, T., Sharmanov, V., Kopytova, A. (2017). Risk-based approach in valuation of workplace injury rate for transportation and construction industry. In: IOP Conf. Series: Earth and Environmental Science, $90,012065$. DOI:10.1088/1755-1315/90/1/012065

Reizgevičius, M., Ustinovičius, L., Rasiulis, R. (2013). Efficiency Evaluation of 4D CAD Model. Procedia Engineering, 57, pp. 945-951.

Sharmanov, V.V., Mamaev, A.E., Boleiko, A.S., Zolotova, J.S. (2015). Difficulties of incremental BIM implementation. Construction of Unique Buildings and Structures, 10, pp. 108-120.

Ziganshin, A., Ziganshin, M. (2018). Smart BIM HVAC. Information modeling in heating and ventilation systems. Kazan: Kazan State University of Architecture and Engineering, $251 \mathrm{p}$. 


\title{
ОСОБЕННОСТИ ПРОЕКТИРОВАНИЯ ИНЖЕНЕРНЫХ СИСТЕМ С ИСПОЛЬЗОВАНИЕМ ИНФОРМАЦИОННОГО МОДЕЛИРОВАНИЯ
}

\author{
Оксана Николаевна Медведева', Татьяна Николаевна Сауткина ${ }^{2}$ \\ 1,2Саратовский государственный технический университет имени Гагарина Ю.А. \\ Политехническая ул., 77, г. Саратов, Россия
}

${ }^{1}$ Автор, ответственный за переписку: medvedeva-on@mail.ru

\begin{abstract}
Аннотация
Введение. На сегодняшний день технологии информационного моделирования зданий и сооружений активно применяются в строительной индустрии и помогают автоматизировать процессы проектирования, начиная с процесса фрормирования чертежей и заканчивая составлением спецификаций. Большую помощь использование ВIM технологий оказывает при проектировании и оформлении разделов инженерных систем (отопления, вентиляции, наружных сетей газо-, водоснабжения), поскольку позволяют избежать возникновения различных проектных ошибок. Цель исследования: Цель данной статьи - обзор особенностей создания информационной модели инженерных систем и анализ возникающих проблем в процессе проектирования. Методы: использованы методы теоретического исследования, Результаты: изучены механизмы инсормационного моделирования инженерных систем, отмечены проблемы, возникающие в процессе разработки проектной документации, предложены пути решения кадровых проблем.
\end{abstract}

\section{Ключевые слова}

Информационное моделирование, ВІМ-платформа, инженерные системы, технологии, инновации 